\title{
O CONTEXTO DA VIOLÊNCIA SEXUAL CONTRA CRIANÇA E A NECESSIDADE DE UMA CULTURA DE PROTEÇÃO FAMILIAR E ECLESIAL
}

\author{
[The context of sexual violence against children and the need for a culture of \\ family and ecclesial protection]
}

\author{
VARIOS AUTORES ${ }^{1}$
}

\begin{abstract}
Resumen
Existe uma lacuna no que se refere ao estudo sobre quem são os autores da violência sexual (AVS) contra criança e o ambiente que ela ocorre. A compreensão destes elementos é importante na determinação de estratégias de proteção e prevenção a violência sexual infantil. Desta forma, o presente artigo intenta discutir sobre o cenário em que a violência sexual contra a criança transcorre, utilizando a cidade de Curitiba/PR no Brasil, para o estudo de caso, buscando elementos relevantes na criação de uma cultura social e eclesial de proteção e prevenção a violência. A pesquisa foi efetuada utilizando o método exploratório descritivo e quantitativo, mediante a análise documental de 76 processos criminais eletrônicos, julgados em primeira instância na Vara de Infrações Penais contra Crianças, Adolescentes e Idosos, no município de Curitiba, nos quais o AVS foi condenado em primeira instância com recurso no Tribunal de Justiça do Estado do Paraná, Brasil. Nos 76 processos analisados a idade do AVS variou de 17 a 73 anos, com média de 42,63 anos. Quase a totalidade dos crimes avaliados foram cometidos por homens e o estudo revela que os processos são em maioria (92\%) de vítimas do sexo feminino, cuja média de idade foi de 8 anos. Os dados revelam ainda que os crimes ocorrem, na maioria das vezes, em ambiente familiar, sendo praticados por pessoa próxima e da
\end{abstract}

\footnotetext{
1 Daiane Priscila Simão-Silva, Bióloga, doutora em Genética e pós-doutorado em Bioética. Pesquisadora no Instituto para Pesquisa do Câncer, IPEC. Guarapuava, Paraná, Brasil. Email: dpscientist@gmail.com; Célia Inês da Silva, Formada em Direito. Mestre em Bioética, Docente da Escola de Direito da Pontifícia Universidade Católica de Curitiba, Paraná. Brasil. E-mail: celiasil2008@hotmail.com; Eliane Freire Rodrigues de Souza De Carli, Coordenadora do Núcleo Lux Mundi na Conferência dos Religiosos do Brasil e Conferência Nacional dos Bispos do Brasil, Médica Pediatra, graduada em direito. Mestranda no Programa de Pós Graduação Interdisciplinar em Desenvolvimento Comunitário na UNICENTRO - Guarapuava Paraná. Brasil. E-mail: elianefdecarli@gmail.com; Renata Cristina Alves da Rocha, Graduada em Psicologia Especializanda em Neuropsicologia (FAE - Centro Universitário) - Curitiba Paraná - Brasil. Email: renatacrisrocha0610@gmail.com; Houda Izabela De Oliveira, Enfermeira, Mestre em Bioética, Enfermeira no Hospital Pequeno Príncipe. Docente na Faculdade Pequeno Principe, E-mail: houda.izabela@yahoo.com.br; Valdecir Badzinski, Padre da Diocese de Guarapuava (PR), Mestrando em Teologia e Sociedade, PUC PR. E-mail: valdecir132@hotmail.com; Jefferson Soares da Silva, Graduado em Pedagogia, Mestre em Educação. Doutro em Teologia, Consultor pela Genitore consultoria Parental, vocacional e no Luto; Mario Antônio Sanches, Licenciado em Filosofia. Mestre em Antropologia Social. Doutor em Teologia. Pós doutor em Bioética, Professor do Programa de Pós-graduação em Bioética- PUCPR.
} 
Varios autores: o contexto da violência sexual contra criança e a necessidade de uma cultura de proteção familiar

confiança da criança, das mais variadas faixas etárias. A banalidade desse mal revela a necessidade de um olhar diferenciado voltado ao AVS, não para justificá-lo, mas para combater o ato cometido a partir de sua origem, a partir de uma mudança cultural, que promova proteção à criança como valor de cuidado para com a vida.

Palavras-chave: Abuso sexual infantil. Autor da violência sexual. Família.

\section{Abstract}

There is a gap with regard to the study of who are the perpetrators of sexual violence (PSV) against children and the environment that occurs. Understanding these elements is important in determining protection and prevention against child sexual violence. Thus, this article intends to discuss the scenario in which sexual violence against a child occurs, using the city of Curitiba / PR in Brazil, for the case study, looking for relevant elements in the creation of a social and ecclesial culture of protection and preventing violence. The research was carried out using the exploratory descriptive and quantitative method, through the documentary analysis of 76 electronic criminal cases, judged in the first instance in the Criminal Offenses Court against Children, Adolescents and Elderly, in the city of Curitiba, in which the PSV was convicted in first instance of the appeal in the Court of Justice of the State of Paraná, Brazil. In the 76 cases resulting, the age of the PSV ranged from 17 to 73 years, with an average of 42.63 years. Almost all the crimes taken were committed by men and the study reveals that the lawsuits are in the majority (92\%) of female victims, whose average age was 8 years. The data also reveal that the crimes occur, most of the time, in a family environment, being committed by a close person and the child's trust, from the most varied age groups. The banality of this evil revelation of the need for a differentiated look towards the PSV, not to justify it, but to combat the act committed from its origin, from a cultural change, that promotes protection of the child as a value of care for With the life.

Keywords: Child sexual abuse. Author of sexual violence. Family.

DOI: $10.7764 / R L D R .11 .135$ 
Varios autores: o contexto da violência sexual contra criança e a necessidade de uma cultura de proteção familiar

\section{INTRODUÇÃO}

Pensar uma "cultura da violência sexual" não necessariamente indica que todos os homens, mulheres, seres humanos em geral, são diretamente responsáveis pela prática da violência sexual. Todavia, indicadores apontam a que a cultura do estupro e da misoginia contribuem rigorosamente para perenização da violência sexual, também infantil, com ênfase, contra o gênero feminino. Com isso, assevera-se a não identificação da figura do abusador unicamente como mero produto da sociedade ou enquanto perturbação mental. Tal movimento designaria uma equivocada percepção sobre o tema. Tampouco compreender a violência sexual mediante a tradicional concepção falocêntrica de conjunção carnal (CHAUÍ, 2009)².

Os crimes de violência sexual infantil, considerados hediondos na legislação brasileira (BRASIL, 2009), ocupam, há muitos anos, espaços relevantes de discussão não apenas no país, mas no mundo inteiro. A mobilização da sociedade e de órgãos competentes visa a amenizar o sofrimento das vítimas e suas famílias e penalizar o Autor da Violência Sexual (AVS), uma vez que a vulnerabilidade e submissão da criança estão diametralmente opostas ao poder e autonomia do violentador. Contudo, a maioria dos estudos concentra-se na área da psicologia e com foco na criança vítima da violência, havendo uma lacuna no que se refere ao AVS.

\footnotetext{
${ }^{2} \mathrm{O}$ termo cultura, de origem latina, "colere", em relação à terra, cultivo; em relação aos deuses, culto; no que tange às crianças, o conjunto e potencialidades que permitem um desenvolvimento saudável, a puericultura. Cientes, hoje, que as identidades culturais não conformam "sistemas fechados", antes, um "colar de significações renováveis pela cristalização de cada nova síntese", cabe refletir sobre o que se compreende por cultura assentados nessas divisas, todavia, arqueáveis por diversidades constitutivas intensificadas pelo comportamento humano (CHAUí, 2009).
} 
Varios autores: o contexto da violência sexual contra criança e a necessidade de uma cultura de proteção familiar

Segundo Krug et al. (2002), a violência sexual é um problema de saúde pública, vitimando crianças e adolescentes em todo o mundo, sem discriminação de raça, cor, religião e status social, econômico e cultural. Apesar de ser um ato moralmente reprovável e mundialmente combatido, a violência sexual contra criança e adolescente, segundo dados do serviço de denúncias Disque 100, apresenta números imódicos. No Brasil, no período de 2011 a 2014, foram 112.684 denúncias desse crime (10.699 em 2011, 40.699 em 2012, 35.691 em 2013 e 25.595 em 2014), constatando-se que, em 2012, o número de abusos sexuais contra esse público foi quatro vezes maior que em 2011, mantendo-se em altos patamares nos anos seguintes (CHILDHOOD, 2017). Em 2019 foram registradas no Brasil 17.000,00 ocorrências de abuso sexual contra criança ou adolescentes e segundo informação do próprio Ministério o número se manteve estável em comparação a 2018, apresentando queda de 0,3\%, mas em relação a 2011, houve um aumento de 41\% nestes números. Inúmeras pesquisas têm demostrado que a violência sexual resulta em graves consequências físicas e psicológicas para a vítima, como também viola os direitos humanos e o direito ao desenvolvimento sadio da sexualidade, garantidos pela Constituição Federal e pelo Estatuto da Criança e do Adolescente (ECA) (BRASIL, 1990).

Não obstante, apesar da constatação de números de registro elevados de casos de violência sexual contra crianças, faz-se necessário investigar quem é o AVS e porque este crime continua a ocorrer em larga escala. Acontece mesmo diante de mobilização social, seja pela criação de legislação, incremento e divulgação da proteção à criança e da punição e reabilitação do indivíduo, seja pela instituição de programas e políticas públicas que articulam o combate mediante plano específico de enfrentamento da violência sexual contra a criança e adolescente. E recentemente, também como movimento Eclesial, com as iniciativas do Vaticano arregimentadas pelos documentos Vademecum (2019) com orientações no tratamento dos casos de abusos sexual de menores cometidos por clérigos e o motu próprio Vos estis lux mundi promulgado em 2019 pelo Papa Francisco.

No Brasil, o Plano Nacional de Enfrentamento da Violência Sexual contra Crianças e Adolescentes (PNEVSCA), criado em 2000, trouxe muitas alterações, inclusive constatando 
Varios autores: o contexto da violência sexual contra criança e a necessidade de uma cultura de proteção familiar

pela primeira vez a necessidade de oferecer tratamento e acompanhamento ao AVS (BRASIL, 2013). No relatório de monitoramento relativo ao período de 2003-2004, elaborado pelo Comitê Nacional de Enfrentamento à Violência Sexual contra Crianças e Adolescentes, constam estratégias obrigatórias para promover a erradicação da violência sexual, como uma mobilização social séria, comprometida efetivamente com a articulação e manutenção dos propósitos. Além da importância da mídia na divulgação de alerta à sociedade acerca desses crimes, distante do sensacionalismo, mas sóbria e constante, atenta à contextualização da violência e promoção do debate sobre esses fatos, mantendo o tema em evidência, a despeito da carência de dados (BRASIL, 2006).

Muitos dos objetivos, ações e metas do PNEVSCA, traçados em 2006 e 2010, não foram efetivados, atestando sua necessária revisão, que ocorreu em 2013. Atualmente, prevê, além do atendimento e tratamento do AVS, o aperfeiçoamento da sua responsabilização penal, o aprimoramento do sistema de responsabilização na apuração desses crimes e a promoção da participação ativa das crianças e adolescentes na defesa de seus direitos, convertendo-os em agentes multiplicadores de sua própria proteção contra a violência sexual (BRASIL, 2013).

Apesar de a temática não ser escassa na literatura, parcos são os trabalhos com foco no AVS; especificamente, na cidade de Curitiba, não foram identificados estudos cujo objetivo fosse traçar ou identificar um perfil socioeconômico do AVS, condenado pela prática do crime de violência sexual contra criança de zero a 12 anos. Aliás, essa faixa etária não é contemplada de forma satisfatória na literatura, pois a maioria dos estudos abrange a temática da violência contra crianças e adolescentes de zero a 18 anos, sem foco na infância - zero a 12 anos, conforme critério estabelecido na Lei no 8.069/1990, em seu art. 2ㅇ (BRASIL, 1990).

A temática invoca profusos questionamentos, tais como: por que o crime continua ocorrendo? Seria a falta de legislação? Um problema cultural? Ou de poder sobre a população infantil? Por que, apesar de todo o desenvolvimento tecnológico e cultural, esse 
Varios autores: o contexto da violência sexual contra criança e a necessidade de uma cultura de proteção familiar

crime continua sendo um problema mundial, sem efetividade em sua prevenção e erradicação? Qual é o papel das Igrejas e da religião neste processo?

Lastimavelmente, a violência sexual não é uma novidade contemporânea; antes, concatena-se à história da humanidade, ostentando contornos progressivamente mais incompreensíveis, incorporados ao cotidiano com certo grau de normalidade. Diante disso, algumas poucas pesquisas e estudos retomam o aspecto psicológico do AVS, objetivando prevenir e impedir a ocorrência desse infortúnio. Contudo, por efeito da complexidade e amplitude do tema, identifica-se a pertinência da discussão no âmbito da bioética, por circundar princípios da autonomia, liberdade e moralidade, intencionando encontrar modos atualizados de enfrentamento, mediante discussões multidisciplinares de um fenômeno com ampla dimensão social. De outra forma, o perfil do AVS não pode ser compreendido homogêneo ou categoricamente, tampouco a violência deve ser compreendida trivialmente. Sendo assim, o presente artigo tem por objetivo refletir sobre o cenário em que a violência sexual contra criança ocorre, utilizando a cidade de Curitiba/PR no Brasil, para o estudo de

caso, buscando elementos importantes na criação de uma cultura social e eclesial de proteção e prevenção a violência.

\section{METODOLOGIA}

A presente pesquisa foi efetuada utilizando o método exploratório descritivo e quantitativo, mediante a análise documental de 76 processos criminais eletrônicos, julgados em primeira instância na Vara de Infrações Penais contra Crianças, Adolescentes e Idosos, no município de Curitiba, nos quais o AVS foi condenado em primeira instância com recurso no Tribunal de Justiça do Estado do Paraná, Brasil. A discussão foi tecida considerando referenciais da bioética. 
Varios autores: o contexto da violência sexual contra criança e a necessidade de uma cultura de proteção familiar

\section{DETERMINAÇÃO DA AMOSTRA}

A aquiescência com a pesquisa, processou-se na Vara de Infrações Penais contra Crianças, Adolescentes e Idosos de Curitiba, sendo instaurado um processo administrativo para obter o parecer do representante do Ministério Público, manifestação e deferimento pelo presidente do Tribunal de Justiça do Estado do Paraná. O processo foi autuado sob no 0002027-89.2015.8.16.0007, em 23 de setembro de 2016, com termo de responsabilização da pesquisadora acerca dos dados existentes nos processos, relativos à identificação do AVS e da vítima, visto que esses processos tramitam em segredo de justiça, ou seja, a consulta aos autos somente é permitida às partes, seus advogados, julgador, promotor e funcionários da secretaria do cartório ou câmara em que estejam tramitando.

No início do trabalho, deparou-se com a impossibilidade de coleta nos processos em que o AVS foi condenado em primeira e segunda instância, durante os anos de 2012 a 2015, como originariamente pretendido, pois, além de não serem mais recentes, tramitaram até 2013 em forma física e foram arquivados em caixas de arquivo por ano de baixa definitiva do tribunal, sem informação acerca da idade da vítima e do crime, exigindo primeiramente a consulta no sistema de acompanhamento de processos físicos, com sua posterior localização nas caixas para análise e início da coleta de dados, optando então pela coleta de dados apenas em processos com tramitação eletrônica, julgados em primeira instância e em fase de julgamento pela segunda instância, devido à interposição de recurso pelo AVS condenado em primeira instância.

Foram excluídos da pesquisa os casos cuja vítima, na data do crime, tinha acima de 12 anos de idade, além daqueles processos julgados que, mesmo tratando de casos de crimes contra vulneráveis, não envolviam violência sexual, como, por exemplo, violência física, abandono e negligência. 
Varios autores: o contexto da violência sexual contra criança e a necessidade de uma cultura de proteção familiar

Os dados foram extraídos dos documentos que compõem os processos judiciais, especificamente, o boletim de ocorrência (documento lavrado no momento da notícia do abuso), a denúncia oferecida pelo representante do Ministério Público, o interrogatório e vida pregressa do AVS e a sentença judicial. Essa análise de documentos foi imprescindível, pois, no boletim de ocorrência, não existem dados do suposto agressor, que são coletados pela autoridade judicial (delegado) durante a fase do inquérito policial, no qual são colhidos depoimentos e feito o interrogatório. Encerrado o inquérito, o delegado envia os autos para o representante do Ministério Público responsável pela denúncia, que devem conter todas as informações relativas ao crime e às partes, como também relatório pormenorizado dos fatos, sendo, portanto, um documento importante no qual constam informações imprescindíveis para a pesquisa. Na sentença, também há um relatório, mas seu objetivo não é a informação sobre qualquer das partes e, sim, sobre o crime e a decisão final do juiz, condenando ou não o AVS.

\section{COLETA DOS DADOS}

A coleta dos dados foi iniciada após a aprovação do projeto de pesquisa submetido ao Comitê de Ética da Pontifícia Universidade Católica do Paraná (PUCPR), conforme Parecer no 1.524 .366 , de 1 o de maio de 2016.

A Lei no 11.419, de 19 de dezembro de 2006, dispõe sobre a informatização dos processos judiciais e, apesar de sua criação ter ocorrido naquele ano, somente em 2011, o Processo Judicial Digital (Projudi) passou a ser utilizado nas varas judiciais. Na Vara de

Infrações Penais contra Crianças, Adolescentes e Idosos, o sistema eletrônico somente foi instalado em junho de 2014; por esse motivo, nesta pesquisa, foram analisados os processos julgados em 2014, 2015 e 2016, em trâmite com recurso no Tribunal de Justiça do Estado do Paraná. 
Varios autores: o contexto da violência sexual contra criança e a necessidade de uma cultura de proteção familiar

Foi constatado que nem todos os dados estavam presentes na ficha de interrogatório e vida pregressa, partindo-se, então, para a coleta de dados também no boletim de ocorrência, na denúncia, na sentença ou outro documento anexado aos autos. A partir da leitura desses documentos, somaram-se outros dados para coleta, como a data do boletim de ocorrência, a idade e o sexo da vítima, a data e o local do crime, a filiação da vítima, a data da denúncia, a data da sentença, a situação prisional do AVS e anotações gerais.

Além desses dados, foram também anotadas informações acerca do abuso e da estrutura familiar, pois evidenciava-se sua importância para a pesquisa qualitativa que se pretendia realizar. Foi mantida fidelidade à nomenclatura usada nos documentos examinados. Constatou-se que uma grande quantidade de dados inexistia nos autos, permanecendo uma lacuna e gerando, na elaboração das tabelas e gráficos, o título "não consta".

\section{RESULTADOS}

Foram selecionados 76 processos criminais, julgados em 2014, 2015 e 2016, nos quais o AVS foi condenado pelo crime de violência sexual envolvendo crianças de até 12 anos e aguardavam julgamento de recurso pelo Tribunal de Justiça. A pesquisa de dados foi realizada em curto espaço de tempo (setembro a novembro de 2016), tornando-se possível apenas pela condição da pesquisadora, advogada formada em 1986, atuando há quase 30 anos e já familiarizada com os termos e procedimentos judiciais.

Constatou-se que a idade do AVS variou de 17 a 73 anos, com média de 42,63 anos

(Desvio Padrão - DP = 13,85; mediana = 41,00; Q1 = 31,25; Q2 = 41,00; Q3 = 52,75) , sendo

\footnotetext{
${ }^{3}$ DP é uma medida de dispersão dos dados em relação à média. Um valor alto indica que os dados estão dispersos da média. Por sua vez, os Qs representam a distribuição das idades em quatro partes iguais, situando sobre a dispersão dos dados, considerando a mediana.
} 
Varios autores: o contexto da violência sexual contra criança e a necessidade de uma cultura de proteção familiar

quase a totalidade desse contingente do sexo masculino; encontrou-se apenas um AVS do sexo feminino, madrasta da vítima.

Quanto à escolaridade do AVS, praticamente um terço $(32,9 \%)$ cursou o ensino médio e, em 14,5\% dos processos, não constava a informação, conforme Tabela 1.

Tabela 1 - Escolaridade.

\begin{tabular}{lrr}
\hline \multicolumn{1}{c|}{ Escolaridade } & $\mathrm{n}$ & $\%$ \\
\hline Analfabeto & 2 & 2,6 \\
Ensino fundamental & 6 & 7,8 \\
Ensino fundamental incompleto & 19 & 24,7 \\
Ensino médio & 16 & 20,8 \\
Ensino médio incompleto & 10 & 13,0 \\
Ensino superior & 7 & 9,1 \\
Ensino superior incompleto & 5 & 6,5 \\
Pós-graduado & 1 & 1,3 \\
Não consta & 11 & 14,3 \\
\hline
\end{tabular}

Fonte: A autora (2017).

Notas: Foram agrupados, dentro dos níveis educacionais, os AVSs de escolaridade completa ou incompleta. Para o ensino fundamental I, considerou-se da 1a à 4a série. Para o ensino fundamental II, considerou-se da 5a à 8ạ série.

Nesta pesquisa foi constatado que 92\% das vítimas eram meninas. Já a idade das crianças vítimas de violência sexual era de três meses a 12 anos, apresentando média de idade de oito anos.

Quanto à relação do AVS com a vítima, a pesquisa apontou que quem mais comete o ato de violência sexual contra a criança é o padrasto/madrasta (26,3\%), seguido de 
Varios autores: o contexto da violência sexual contra criança e a necessidade de uma cultura de proteção familiar

conhecido/vizinho $(25,0 \%)$, outros parentes $(19,7 \%)$, avós $(13,2 \%)$, pais da vítima $(7,9 \%)$ e, com igual proporção, professor e desconhecido/internet (3,9\%).

Neste estudo, foi identificada uma correlação entre a relação do AVS com a vítima e o tempo de abuso $(\rho=-0,299 ; p=0,009)$, ou seja, quanto mais próximo do convívio com a vítima estiver o AVS, maior será o tempo de duração da violência sexual, conforme pode ser verificado no Gráfico 1.

Gráfico 1 - Relação do AVS com a vítima x tempo de abuso.

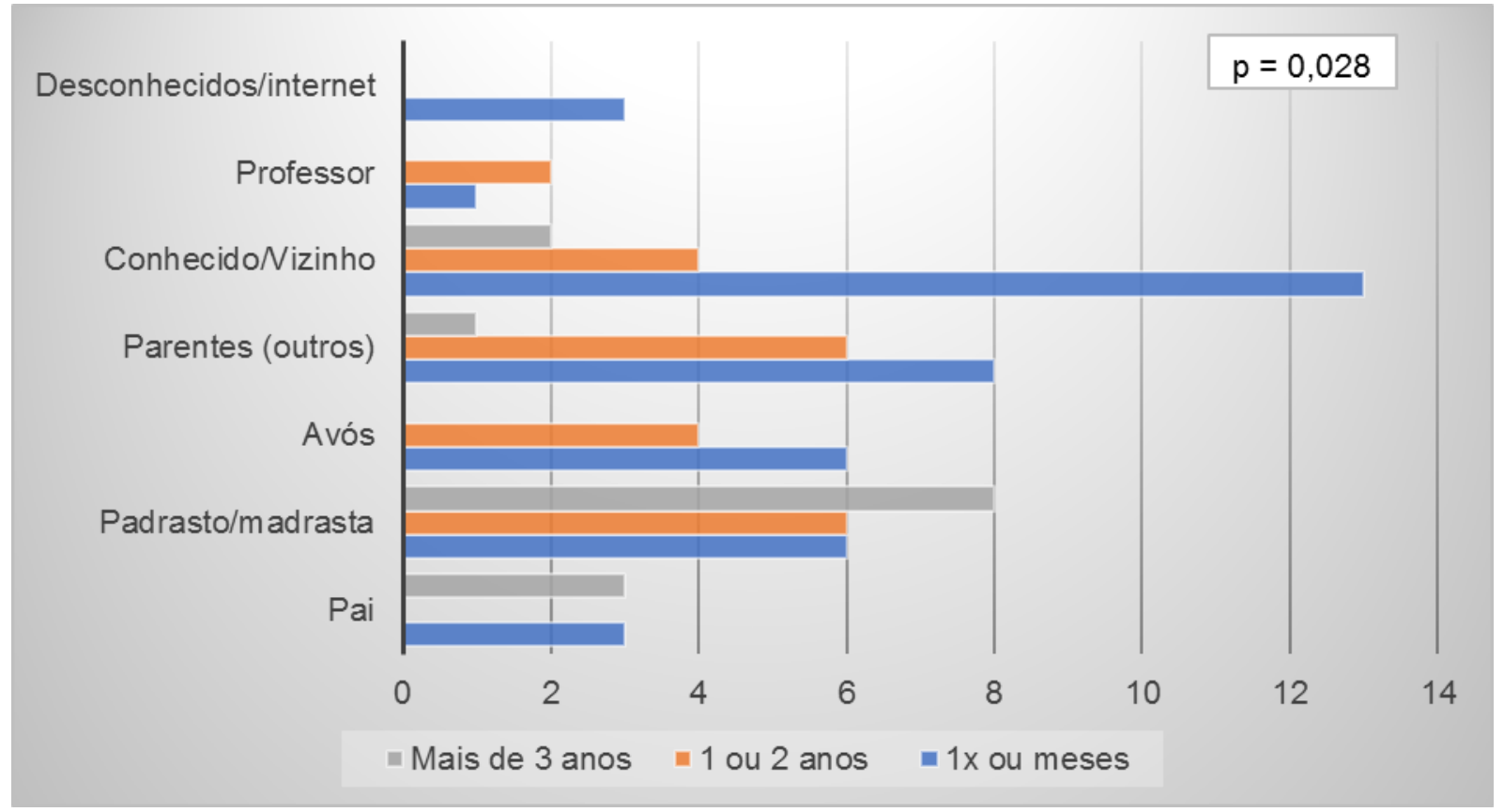

Fonte: A autora (2017).

Os crimes de abuso sexual ocorreram na residência do AVS (28,9\%), na residência do AVS e da vítima (28,9\%), na residência da vítima (22,4\%), em outros lugares (9\%), na casa dos avós (5\%), na escola (3\%) e na internet (3\%). A duração da violência sexual variou de um mês a nove anos (Tabela 2). Ainda, o crime foi constituído por atos libidinosos (76,3\%), estupro $(22,4 \%)$ e aliciamento de menor $(1,3 \%)$.

Tabela 2 - Duração da violência sexual. 
Varios autores: o contexto da violência sexual contra criança e a necessidade de uma cultura de proteção familiar

\begin{tabular}{|c|c|c|c|c|c|c|c|c|}
\hline & \multicolumn{9}{c|}{ Relação com a vítima } \\
\hline Duração & Pai & $\begin{array}{c}\text { Padrasto/ } \\
\text { madrasta }\end{array}$ & Avós & Parentes & $\begin{array}{c}\text { Conhecido/ } \\
\text { vizinho }\end{array}$ & Professor & $\begin{array}{c}\text { Desconhecidos/ } \\
\text { internet }\end{array}$ & Total \\
\hline $\begin{array}{c}\text { Uma vez ou } \\
\text { meses }\end{array}$ & 3 & 6 & 6 & 8 & 13 & 1 & 3 & 40 \\
\hline $\begin{array}{c}\text { 1 ou 2 anos } \\
\text { Mais de 3 Anos }\end{array}$ & 0 & 6 & 5 & 6 & 4 & 2 & 0 & 22 \\
\hline Total & 6 & 8 & 0 & 1 & 2 & 0 & 0 & 14 \\
\hline
\end{tabular}

Fonte: A autora (2017).

Este estudo revelou correlação entre o tempo de duração da violência sexual e o ano em que o crime ocorreu $(\mathrm{J}=-0,597 ; \mathrm{p}=0,008)$, conforme o Gráfico, sendo que, nos anos de 2013 a 2015, o tempo de duração do abuso diminuiu de um ou dois anos para uma vez ou meses.

Gráfico 2 - Ano de início ou ocorrência da violência x tempo de ocorrência.

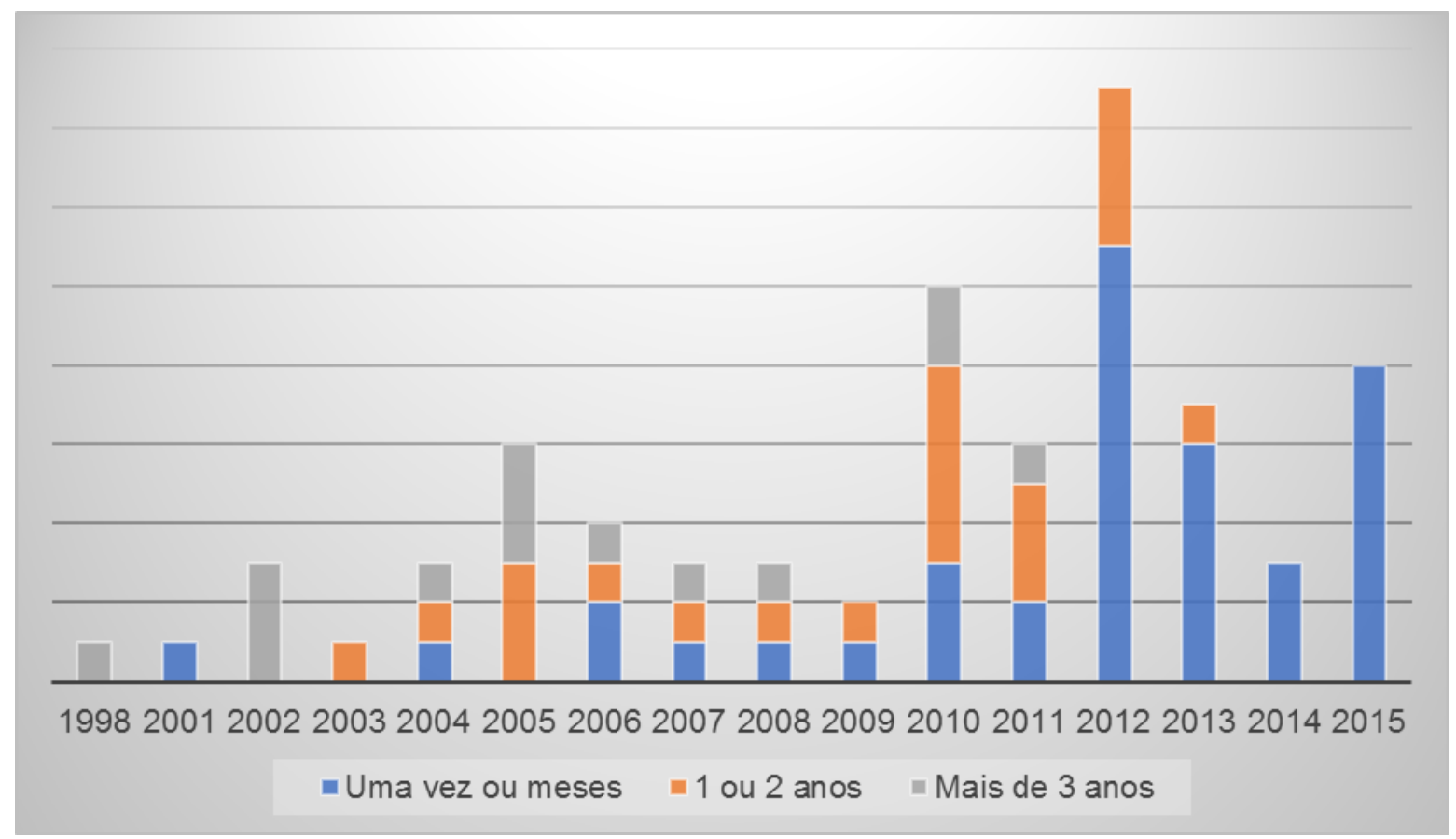

Fonte: A autora (2017).

\section{DISCUSSÃO}


Varios autores: o contexto da violência sexual contra criança e a necessidade de uma cultura de proteção familiar

A violência sexual cometida contra crianças de zero a 12 anos, constatada nesta pesquisa, traz à baila a necessidade de reflexão sobre a moralidade comum, a convivência em sociedade, o respeito aos outros, a liberdade, o exercício da autonomia, além da importância da implementação de possíveis fatores de proteção e prevenção à violência.

A relação assimétrica entre AVS e vítima, verificada neste estudo e em várias pesquisas, remete a uma reflexão sobre a gravidade e, consequente, banalidade desse ato. Banalidade constatada mediante o cenário analisado, e que viabilizou a compreensão que os crimes ocorrem, comumente, em ambiente familiar, praticados por pessoa próxima e da confiança da criança, das mais variadas faixas etárias.

As lacunas no preenchimento dos dados de pesquisa denotam a despreocupação do Judiciário em fazer constar nos documentos todos os dados necessários acerca do fato e de todas as pessoas envolvidas. Essa instabilidade ou falta de uniformidade e padronização no preenchimento dos documentos nas delegacias e outros órgãos implica a impossibilidade de traçar um perfil completo do AVS, assim como do conhecimento de dados importantes para o combate e erradicação desse crime.

Além desses obstáculos, enfrenta-se a dificuldade de acesso aos dados, em decorrência da forma como são armazenados os documentos de processos findos. A coleta exige do pesquisador determinado grau de conhecimento sobre a matéria e o processo criminal, de maneira geral, sem o qual a pesquisa é inviabilizada.

A falta de estudos e pesquisas com o objetivo de traçar um perfil socioeconômico do AVS, levando em consideração suas características biopsicossociais, o contexto em que vive e quais aspectos particulares poderiam influenciar seu comportamento, dificulta a tomada de decisões para a implantação de programas de tratamento e a prevenção desse tipo de crime. Conhecer o perfil do AVS pode proporcionar a compreensão de quais contextos direcionam-no para cometer tal ato, sendo preferível prevenir ou impedir o crime, em vez 
Varios autores: o contexto da violência sexual contra criança e a necessidade de uma cultura de proteção familiar

de ser obrigado a puni-lo. A gravidade do crime, que é classificado de hediondo, deveria levar a uma preocupação maior com o caminho percorrido entre ele, sua notificação, o tratamento da vítima e do AVS e o julgamento deste.

Na busca pela identificação de um perfil do AVS, considerando as faixas etárias predominantes em que a violência sexual ocorre, constatou-se que ela é cometida por adolescentes, jovens, adultos e idosos, com idade variando de 17 a 73 anos. A média de idade não diferiu de outro estudo realizado no Paraná, em 2006, no município de Londrina, com 186 notificações de abuso sexual cometido contra crianças de zero a 14 anos. A faixa etária do AVS com maior frequência $(25,4 \%)$ foi de 40 anos, seguida de 30 a 34 anos (21,5\%); em 9,9\% dos casos, o sujeito tinha de 13 a 14 anos (MARTINS e JORGE, 2010).

Para estudos no Sul do Brasil, apesar de realizados em épocas remotas (1992 a 1998 e 2006), a faixa etária foi semelhante à encontrada nesta pesquisa, com relação à média de idade dos AVSs (HABIGZANG et al. 2005; MARTINS e JORGE, 2010). Todavia, a pesquisa realizada em Sergipe (capital e interior), com análise documental no período de 2010 a 2011, revelou que, na capital, 50,4\% da amostra tinha entre 20 e 40 anos (OLIVEIRA, 2013). Outra pesquisa, realizada em processos judiciais em andamento em Belém, Pará, identificou que a idade do AVS era superior a 30 anos na maioria dos casos (57\%). Ainda, demonstrou que, em 96,37\% dos casos, a maior probabilidade de ocorrência relacionava-se a AVS com mais de 30 anos, com filhos, cônjuge e vínculo de parentesco com a vítima (COSTA, 2015).

Diante dos resultados encontrados nesta pesquisa, observa-se que, na problemática da violência sexual contra a criança, não há um padrão etário para o AVS, uma vez que esses crimes são cometidos por sujeitos com apenas 17 anos, como também por idosos com 70 anos ou mais, havendo alguma diferença de prevalência de idade nos diferentes estados da federação. Por outro lado, comparando os dados estatísticos, pode-se concluir que prevalece a idade de 20 a 50 anos. Ademais, deve ser considerada a grande falta dessa informação nos documentos analisados em fartas pesquisas. 
Varios autores: o contexto da violência sexual contra criança e a necessidade de uma cultura de proteção familiar

Comparando a idade do AVS e da vítima, cuja média nesta pesquisa foi de oito anos, constata-se a situação de força, domínio e poder, além do controle exercido sobre a criança, com idades para a vítima variando entre três meses e 12 anos incompletos. Assim como não há padrão etário para cometer a violência, não foi possível categorizar qual fase da infância estaria em maior vulnerabilidade.

No que tange ao gênero do AVS, nesta pesquisa, 99\% dos AVSs eram do sexo masculino, resultado que está de acordo com outras pesquisas, como as de Habigzang et al. (2005) - 98,8\% dos autores do sexo masculino -, Costa (2015) - 98,0\% -, Martins e Jorge (2010) - 97,3\% -, Oliveira (2013) - 94,6\% - e Pincolini et al. (2012) - 96,0\%. Apenas em um dos casos, neste estudo, a violência sexual foi cometida por AVS do sexo feminino, madrasta da vítima.

Com relação à vítima, foi constatado que 92\% eram do gênero feminino. Dados da região de Curitiba relativos a crianças de zero a 12 atendidas em um hospital infantil, vítimas de violência sexual, entre os anos de 2013 e 2015, revelam que 59\% das vítimas eram meninas e $41 \%$, meninos ${ }^{4}$. Essa informação mostra um número bem maior de meninos vítimas de violência sexual infantil do que aqueles encontrados nesta e em outras pesquisas. O que pode evidenciar um alerta acerca de a subnotificação ser ainda maior quando a vítima é menino, o que pode ocorrer por vergonha da família, culpa e vergonha da vítima, como também por questões de gênero.

Lavoratti (2013) constatou, em sua pesquisa realizada em Curitiba, de 2000 a 2010, que as meninas aparecem como as principais vítimas, em $79 \%$ dos casos denunciados. De modo semelhante, Habigzang et al. (2005), ao analisar 71 expedientes de casos denunciados pelo Ministério Público de Porto Alegre, ajuizados entre 1992 e 1998, relataram que predominou o gênero feminino em 80,9\% dos casos de abuso sexual. Martins e Jorge (2010)

\footnotetext{
${ }^{4}$ Dados provenientes de comunicação pessoal, em 2016.
} 
Varios autores: o contexto da violência sexual contra criança e a necessidade de uma cultura de proteção familiar

também apontaram o predomínio de vítimas do gênero feminino (74,2\%), com proporção de 2,9 meninas para cada menino. Ainda, nos registros do Sinan, em 2011, foram atendidas 10.425 crianças e adolescentes vítimas de violência sexual, sendo a grande maioria do gênero feminino (83,2\%) (WAISELFISZ, 2012).

A prevalência do cometimento de violência sexual pelo gênero masculino contra o feminino indica a presença constante de um traço cultural de dominação, autoridade e poder. Nos séculos XIX e XX, a mulher ainda era considerada incapaz, inclusive pela legislação civil, sendo submissa ao pai e posteriormente ao marido. No fim do século XX, as conquistas originárias dos direitos humanos e movimentos feministas começaram a ter seus primeiros resultados, passando a mulher a ter o direito constitucional (BRASIL, 1988) de ocupar um lugar de igualdade no lar conjugal, modificando aos poucos sua situação de subserviência, mas nem assim se livrou do subjugo masculino. Vale situar que o crime de estupro, que até 2009 era descrito pelo Código Penal como crime de ação privada contra os costumes, foi alterado, a partir de então, pela revisão do código pela Lei № 12.015, de 7 de agosto de 2009 (BRASIL, 2009), passando a ser definido como um crime contra a dignidade e liberdade sexual. A situação anterior à Lei no 12.015/2009 legalizava o crime de estupro cometido contra a mulher pelo marido, visto que um dos deveres do casamento era a relação sexual (CERQUEIRA e COELHO, 2014).

Nesse contexto, salienta-se que, para as meninas, a vulnerabilidade é acentuada pelo fator infância, estágio de desenvolvimento físico e emocional e de autonomia em construção. A criança, nesse período da vida, necessita de segurança e, por uma questão natural, confia nos adultos. A quebra da confiança pelo cometimento do abuso de forma manipuladora pelos AVSs causa à vítima consequências muitas vezes insuperáveis, que, se não tratadas de forma eficaz, podem torná-la, inclusive, um AVS na fase adulta.

Os resultados revelam que mais de $50 \%$ dos AVSs eram parentes das vítimas e o menor número era de desconhecidos. A maior incidência de violência sexual constatada foi 
Varios autores: o contexto da violência sexual contra criança e a necessidade de uma cultura de proteção familiar

de natureza intrafamiliar, cometida por pessoa que deveria estar protegendo a criança. Nesse contexto, verificou-se que o AVS tinha uma família de origem; em 96,1\% dos casos, sua filiação materna e paterna foi registrada, dado semelhante ao encontrado por Lung e Huang (2004), em que $87,2 \%$ dos AVSs incestuosos tinham pai e mãe vivos na época do crime. No entanto, esse dado não consta em nenhuma pesquisa, trabalho ou estudo anteriormente realizado no Brasil, sendo esta a primeira pesquisa a trazer a informação. Cumpre destacar que esse dado é importante para traçar o perfil socioeconômico do AVS, visto que $96,1 \%$ deles tiveram seu reconhecimento civil quando nasceram; portanto, tinham uma família de origem. Apesar de presumir-se que foram criados no seio de uma família, esse fato não comprova que cresceram livre de violências, negligência, abandono, separação dos pais etc.

Quanto à relação do AVS com a vítima, a pesquisa apontou que quem mais comete o ato de violência sexual contra a criança é o padrasto/madrasta, seguido de conhecido. Corrobora esses dados a pesquisa de Martins e Jorge (2010), segundo a qual, em 30,1\% dos casos, o AVS era o padrasto da vítima, seguido de outros parentes, como tios, cunhados e primos $(21,5 \%)$, além de vizinhos $(18,3 \%)$, amigos da família $(8,6 \%)$ e pais $(7,0 \%)$. Os autores encontraram, ainda, que entre os AVSs 4,8\% eram colegas da escola; 3,8\%, desconhecidos; 1,2\%, namorados da mãe; 1,2\%, porteiro do prédio; 1,1\%, vendedor de lanche na escola; 0,5\%, mãe; 0,5\%, babá; 0,5\%, caseiro da chácara; e 1,1\% não foi informado.

Lavoratti (2013) aponta que, nas notificações realizadas no período de 2003 a 2010, em Curitiba, o pai biológico aparece em 28,3\% dos casos; o padrasto, em 24,0\%; tio(a), em 12,0\%; avô(ó), 7,9\%, além de outros familiares ou responsáveis pela criança, como primos, cunhados, vizinhos e babás $(19,7 \%)$, ou seja, pessoas que possuem vínculos e uma relação bastante próxima com a vítima. A pesquisa do IPEA de 2013 também constatou que o abuso sexual, em $24,1 \%$ dos casos, foi cometido por pais ou padrastos e, em $32,2 \%$, amigos ou conhecidos da vítima (LAVORATTI, 2013). Da mesma forma, Habigzang et al. (2005) indicam, 
Varios autores: o contexto da violência sexual contra criança e a necessidade de uma cultura de proteção familiar

em sua pesquisa, que a violência foi cometida pelo pai da vítima em $57,4 \%$ dos casos e pelo padrasto ou pai adotivo em $37,2 \%$.

Pincolini et al. (2012), analisando 229 documentos judiciais, constituídos por denúncias e sentenças judiciais, identificaram que, no abuso sexual intrafamiliar, $27,8 \%$ dos AVSs eram pais da vítima, seguidos pelo padrasto (26,3\%), tios (10,5\%), primos (8,3\%), irmãos (6,0\%), mães (4,5\%), avós (3,8\%) e "avodrastos" (3,8\%); no abuso sexual extrafamiliar, 24,0\% dos abusadores eram totalmente desconhecidos da vítima; 65,5\%, vizinhos e conhecidos; e 10,6\%, professores, instrutores e colegas da escola. Por sua vez, Hohendorff et al. (2014) relatam que o amigo ou conhecido foi o abusador em $28,7 \%$ dos casos, seguido por outros, como professores, estranhos, mãe e madrasta $(23,9 \%)$, pai $(16,6 \%)$, padrasto $(9,3 \%)$, tio $(8,5 \%)$, primo $(6,9 \%)$ e irmão $(6,0 \%)$.

Em todas estas pesquisas, os principais violentadores foram os pais ou padrastos, com porcentagem muita próxima entre eles. Além disso, a grande maioria dos AVSs que não eram pais ou padrastos era uma pessoa próxima da vítima.

Neste trabalho, foi identificada uma correlação entre a relação do AVS com a vítima e o tempo de abuso, ou seja, quanto mais próximo do convívio com a vítima estiver o AVS, maior será o tempo de duração da violência sexual. De modo análogo, Habigzang et al. (2011) constataram que a duração do abuso está relacionada com o local e o AVS. Abusos intrafamiliares "tendem a ter um tempo maior de duração, pois a criança necessita de um tempo maior para perceber que os comportamentos do agressor são abusivos" (HABIGZANG et al. 2011, p. 467).

A violência sexual infantil intrafamiliar é mais frequente do que o estimado, muitas vezes sob a alegação de o pai iniciar a filha na vida sexual ou alegando o AVS que houve o consentimento da vítima. Entretanto, o abuso sexual não pode ser, em nenhuma circunstância, considerado um ato moralmente legítimo, porque carece de entendimento da 
Varios autores: o contexto da violência sexual contra criança e a necessidade de uma cultura de proteção familiar

vítima, que, por ser menor, não tem capacidade para compreensão do ato nem discernimento para decidir, tampouco autonomia pessoal para praticá-lo.

Apesar de estudos demonstrando que a violência contra crianças e adolescentes podem causar doenças psíquicas e comportamentos disfuncionais (TEICHER, et al. 2003), essa prática coercitiva é ainda muito difusa em nossa sociedade, de modo especial, no interior das próprias famílias. Sendo assim, consideram-se urgentes estudos que auxiliem na implementação de programas interdisciplinares de conscientização sobre as consequências nocivas de práticas violentas.

Para Silva et al. (2012), dentre os objetivos das ações de prevenção à violência observa-se, exatamente, a mudança de paradigmas culturais que consideram legítimo o uso da violência dentro do contexto familiar. Investigar quais práticas educativas são fatores de risco ou de proteção para o desenvolvimento de crianças e adolescentes é veemente para a promoção do bem-estar psicofísico-social infantoadolescente, seja para assegurar-lhes "a proteção integral e as oportunidades e facilidades para viver sem violência e preservar sua saúde física e mental e seu desenvolvimento moral, intelectual e social" (Art.2 da Lei no 13.431/2017 - Lei do Depoimento Especial) (BRASIL, 2017). Como também, contribuir na elaboração de programas que desenvolvam estratégias eficazes de intervenção junto a famílias consideradas mais vulneráveis à utilização de práticas educativas de risco.

A heteronomia e a falta de educação sexual e de orientação não permitem à criança discernir se o ato cometido por uma pessoa tão próxima é certo ou errado, imoral ou proibido. Normalmente, ela se torna refém do AVS, sendo acometida por um sentimento de culpa, medo de revelar o abuso, de ser desacreditada. A criança em vulnerabilidade não compreende o ato de violência, porque ele não poderia ser cometido por alguém tão próximo e confiável; isso faz com que o ato se repita e a vítima denuncie a violência somente anos mais tarde. Essa situação prolonga-se porque a criança é incapaz de dizer não e, 
Varios autores: o contexto da violência sexual contra criança e a necessidade de uma cultura de proteção familiar

somente quando adquire autonomia e maturidade, compreende que poderia e deveria ter dito não.

Nesta pesquisa, 56,6\% das vítimas eram filhos de pais separados e 10,5\% não eram reconhecidas pelo pai. Ainda, em $27,6 \%$ dos casos, os pais viviam juntos; em 9,0\%, não constava essa informação; e, em 1,3\%, o pai da vítima era falecido. A maioria dos AVSs $(67,1 \%)$ deveria cuidar e proteger a criança, enquanto $67,1 \%$ das vítimas estavam distantes dos pais e passaram por situações de separação ou desajustes, sendo obrigadas a se adaptar a outras realidades. Por fim, 61,9\% dos AVSs, quando cometeram a violência sexual, mantinham um relacionamento sério adulto, presumindo-se que tinham relações sexuais normais com os parceiros. O que os levaria a cometer a violência, por períodos de tempo contínuos, contra suas filhas, enteadas, sobrinhas e netas?

Os crimes de violência sexual ocorreram na residência do AVS (28,9\%), na residência do AVS e da vítima (28,9\%) e na residência da vítima (22,4\%). Os locais escolhidos pelos AVSs eram parques infantis em condomínio, escadas de prédios, mas a grande maioria ocorria dentro da residência, em momentos em que a mãe estava ausente, trabalhando ou estudando.

A pesquisa de Martins e Jorge (2010), também realizada no Paraná, na cidade de Londrina, corrobora esses dados, uma vez que a maioria dos casos de violência sexual ocorreu na residência da vítima (52,7\%), seguida pela residência do agressor $(30,1 \%)$, residência de parente $(5,4 \%)$, via pública $(4,3 \%)$, escola $(2,4 \%)$, terreno baldio $(0,8 \%)$, outros $(3,8 \%)$ e não informado $(0,5 \%)$.

Habigzang et al. (2005) indicam que a violência sexual ocorreu na casa da vítima em 66,7\% dos casos, encontrando-se ela sozinha com o agressor. Já segundo Pincolini et al. (2012), o abuso deu-se na residência da vítima em 94 dos casos (41\%) dos 229 processos; na residência do AVS em 76 processos (33\%) - que era frequentada pela vítima (casa dos avós, 
Varios autores: o contexto da violência sexual contra criança e a necessidade de uma cultura de proteção familiar

tios, pais separados) -; em locais ermos, como mato, campo e construções (37 casos ou 16\%); e locais públicos e de lazer, como clubes, parques e estabelecimentos comerciais (11 casos ou 5\%). Em relação aos abusos extrafamiliares, escolas e creches (nove casos ou 4\%) constaram como local, como também o interior de veículos (três casos ou 1\%). Em outros sete processos (3\%), não havia informação sobre o local do abuso (HABIGZANG et al. 2005)

De acordo com Hohendorff et al. (2014), em 78,7\% dos casos, a residência da vítima foi o local da ocorrência do abuso, além de moradias coletivas, como unidade de cuidado institucional $(6,5 \%)$, ruas públicas $(5,7 \%)$, escolas $(5,2 \%)$ e outros locais, como lagos e casas abandonadas (3,9\%).

Por fim, Costa (2015), analisando 206 processos, identificou que em 96 casos de abuso sexual intrafamiliar o local foi a residência da vítima, do agressor ou de ambos; em 110 processos de abuso extrafamiliar, 17 casos ocorreram em local público e 83, em local privado, residência da vítima, do agressor ou de ambos.

Ainda no contexto de família, a maioria dos AVSs $(61,9 \%)$ possuía um relacionamento afetivo mais sério. Essa constatação induz à conclusão de que mantinham relação sexual com uma pessoa adulta. Sendo o violentador, na maioria das vezes, pai ou padrasto da vítima, qual seria o motivo para o sujeito que mantém um relacionamento sexual adulto cometer violência sexual contra uma criança que faz parte de sua família, valendo-se de seu poder e força em relação à vulnerabilidade da criança para satisfazer seus desejos?

No que se refere à duração de agressões sexuais contra crianças e adolescentes, Habigzang et al. (2005) concluem que, em 32,2\% dos casos, o abuso teve duração entre um e 11 meses e, em 67,8\%, de um a nove anos. Quanto ao número de vezes, 79,1\% ocorreram mais de uma vez e, em 41,9\%, o abuso era diário. 
Varios autores: o contexto da violência sexual contra criança e a necessidade de uma cultura de proteção familiar

Ainda nesse sentido, Habigzang et al. (2011) afirmam que existe relação entre o período de duração e o contexto em que ocorre. No âmbito extrafamiliar, por exemplo, a agressão sexual tende a ter menor tempo de duração, quando comparada com aquela que ocorre no contexto intrafamiliar. Consoante os autores, o que contribui para uma maior duração dos casos de agressão sexual no contexto intrafamiliar é, principalmente, a dinâmica do segredo, sendo bastante comum no meio familiar, devido ao vínculo próximo da vítima com o autor da agressão. Alguns casos de abuso com maior tempo de duração ocorrem por omissão da mãe da vítima, como constatado nesta pesquisa. Isso se dá pela dificuldade de aceitação da genitora, medo da destruição da família, culpa e vergonha. Há casos, inclusive, em que a mãe é indiciada por omissão.

Costa (2015), por sua vez, informa que o abuso sexual intrafamiliar ocorreu uma única vez em 21 processos e mais de uma vez em 46 processos. O abuso sexual extrafamiliar deuse em 110 processos, ocorrendo uma única vez em 55 e mais de uma vez em 20. Segundo Habigzang et al. (2005), esses resultados estão em consonância com estudos epidemiológicos nacionais e internacionais, que apontam que cerca de $80 \%$ dos casos de abuso sexual contra crianças são perpetrados no contexto doméstico, tendo duração de mais de um ano.

Diante dos dados estatísticos encontrados, confirmados por outros achados em estudos realizados no país, apontando que, em mais de 90,0\% dos casos, o crime foi cometido por abusador do sexo masculino, que mantém um relacionamento sério $(61,9 \%)$ e não possui vícios (42,1\%), destaca-se que o AVS não tem um perfil diferenciado, ou seja, não há informações que determinem ou o caracterizem como praticante da violência, nem mesmo o fato de estar sozinho ou viver na solidão, uma vez que a maioria mantém um relacionamento adulto e a média de idade encontrada aponta para um grau de entendimento e de escolha acerca do ato realizado. A grande maioria dos AVSs tinha profissão e escolaridade razoáveis e residia em bairros populosos, com baixo rendimento per 
Varios autores: o contexto da violência sexual contra criança e a necessidade de uma cultura de proteção familiar

capita. Eles vivem em sociedade, em comunidade, em que existem regras e princípios morais que devem ser observados, mas são ignorados ao se praticar o ato.

Em que pese o ordenamento Jurídico brasileiro ter evoluído muito nas últimas décadas e já há 30 anos. O Estatuto da Criança e do Adolescente ao atribuir normatividade infraconstitucional à doutrina da Proteção integral, delimitou muito bem a abrangência dos direitos desta população em peculiar condição de desenvolvimento. Como explica De Carli (2020. p. 495) “A Doutrina da Proteção Integral assegura direitos fundamentais e a garantia do seu melhor interesse, (...) A questão da violência contra crianças e adolescentes, bem como as medidas de prevenção a serem implementadas, tanto pelo Estado, como pela família e a sociedade, são expressas em todo o texto do Estatuto da Criança e do Adolescentes (...)". Porém, há um abismo entre o que está previsto e o que, de fato, já foi efetivado como garantia de direito da população infantoadolescente. Some-se a isto a falta de integração entre as políticas públicas - Saúde, Educação, Assistência Social, Habitação, Meio ambiente - o sistema de justiça - Poder Judiciário, Ministério Público, Polícia Civil, Defensoria Pública - Terceiro Setor, os quais trabalham, comumente, sem integração, não apenas no que diz respeito aos dados, mas, também, na prática cotidiana. A imprecisão dos dados, diretamente relacionada ao preenchimento incompleto nas delegacias, nos hospitais, no sistema judiciário, etc, denotam certo desinteresse, quiçá, de empatia pelo irreparável sofrimento que este crime causa. Outro fator importante como afirma Joana Ribeiro, magistrada no Estado de Santa Catarina, é que:

Ultrapassado o obstáculo da existência dos direitos, a próxima etapa é a da mensuração dos problemas e da instauração da política pública adequada à garantia. Da mensuração até a estratégia da solução garantidora, o Acesso à Justiça é visto, portanto, como última solução para a concretização destes direitos, assegurados pela Constituição Federal (...) na medida em que há mecanismos não jurisdicionais de solução estabelecidos pelo Estatuto da Criança e do Adolescewnte há 30 anos, os quais devem ser encaminhados antes, por meio do Conselho Tutelar, do Conselho de Direitos e do Ministério Público, em rede com o Sistema Único de Assistência Social - SUAS, cabendo a ação judiciária na hipótese de não 
Varios autores: o contexto da violência sexual contra criança e a necessidade de uma cultura de proteção familiar

superação da estratégia de defesa, proteção e respeito à criança e ao adolescente. (...) Enquanto membro do Poder Judiciário, (...) a sensação pessoal é que há um beco sem saída para a criança e para o adolescente, em que o Juiz pode ser o salvador ou o grande agressor institucional, dada a falta de abertura ao diálogo dos procedimentos do Estatuto da Criança e do Adolescente (RIBEIRO, 2020, p 664666)

A garantia de que crianças e adolescentes terão seus direitos assegurados e que seus agressores serão punidos, está relacionada com uma mudança de paradigma em curso ainda em nosso país. A perspectiva que se apresenta parece, por exemplo, perpassar o trabalho conjunto, por meio da Rede de Proteção da Criança e do Adolescente.

A Constituição Federal de 1988 reconhece em seu artigo 227 (BRASIL, 2010) que o tripé família, sociedade e Estado são igualmente responsáveis pelo reconhecimento da criança e do adolescente como sujeitos de direitos. Portanto, todos devem estar imbuídos deste empenho, pois "A existência e a persistência do abuso sexual não têm relação apenas com os atos dos autores da agressão contra as vítimas, mas também com a capacidade normatizadora, controladora e fiscalizadora da sociedade" (SANTOS, 2009). Este mesmo documento recorda que a sociedade, ao eleger aqueles que farão as Leis do país, estão investindo também na segurança e na construção de uma civilização harmoniosa.

Uma sociedade na qual as normas e os direitos são reconhecidos, discutidos e amplamente divulgados, pode ser favorável à criação de mecanismos protetivos de violência. Nesta mesma seara, a questão ampla da educação como fator protetivo de violência deve ser assinalada. Educar crianças e adolescentes à cultura da tolerância, do respeito ao próximo e da empatia, é garantia de um futuro melhor. Desse modo:

A existência de leis apropriadas e claras contra o abuso sexual, acompanhadas de campanhas educativas, representa um reforço ao cumprimento rigoroso da legislação e punição exemplar dos transgressores, podendo quebrar o ciclo de impunidade que impera nessa área (SANTOS, 2009). 
Varios autores: o contexto da violência sexual contra criança e a necessidade de uma cultura de proteção familiar

Corroborando com este aspecto, Veronese explica que "A questão do acesso à Justiça, o qual não pode ser reduzido a uma mera capacidade de ingressar em juízo, tem em seu fundamento a necessidade de uma maior politização por parte das camadas populares" (VERONESE, 2020. p.19)

A falta de um trabalho conjunto, tanto na prevenção de violência em face de crianças e adolescentes, como no acompanhamento multi/interdisciplinar dos AVS, pode ser responsável pela impunidade e pela perpetuação desta prática. Há eminentes indicações que a denúncia/notificação dos casos de violência sexual contra crianças e adolescentes está longe de ser compatível com a realidade, impactando com a impunidade que vigora em nosso país. A efetivação do prescrito no próprio Estatuto da Criança e do Adolescentes, apesar de ser claro e rigoroso, não é cumprido.

Nos anos de 2013 a 2015, o tempo de duração da violência sexual diminuiu de um ou dois anos para uma vez ou meses. Considerando a dificuldade de revelar o abuso (HABIGZANG et al. 2005; MARTINS e JORGE, 2010; PINCOLINI et al. 2012), a correlação encontrada nesta pesquisa entre o tempo de duração da violência sexual e o ano em que o crime ocorreu aponta para um despertar nesse sentido e, consequentemente, para a interrupção do crime, possibilitando que sejam tomadas providências para evitar danos maiores e reduzidas as consequências. Tal assertiva pode incentivar uma maior divulgação da violência sexual infantil e uma atenção maior para a pessoa do AVS, considerando que a redução da duração do abuso coincide com a apresentação do PNEVSCA, constatando-se que as estratégias implementadas surtiram efeitos positivos, como a verificada na pesquisa, uma vez que a redução da duração do abuso ocorreu durante o período de 2013 a 2015.

Outros aspectos da vida do AVS foram também investigados, como a religião, que em 85,5\% dos casos não foi identificada. Em sua pesquisa, Mayer (2003 apud HABIGZANG et al., 2005) verificou que, em 25 casos, havia registro da religião do agressor, sendo 36\% católicos, 
Varios autores: o contexto da violência sexual contra criança e a necessidade de uma cultura de proteção familiar

$36 \%$ evangélicos, $16 \%$ espiritualistas, $4 \%$ sem religião e $8 \%$ de outras religiões. Já de acordo com a pesquisa de Carvalho e Sousa (2007), em 77 prontuários em que constava essa informação, 57,1\% dos sujeitos eram católicos; $28,6 \%$, evangélicos; $11,7 \%$, sem religião; e $2,6 \%$, de outras religiões. Uma vez que, na maioria das pesquisas, não existe essa informação, tal discussão torna-se limitada.

No que tange ao sentido religioso, considerando que a maioria dos AVS se intitula católicos, identifica-se uma incongruência com os princípios religiosos pois, para doutrina católica, na igreja se constituem os valores fundamentais na sua integralidade, no entendimento que sobre a vida física fundamentam-se e desenvolvem-se perfeitamente os valores da pessoa e, por isso, requer inviolabilidade plena (Documentos Pontifícios - 213, 11). Nesse sentido, a prevenção de violência sexual contra crianças, adolescentes e pessoas em situação de vulnerabilidade é um princípio regulador do "ser Igreja" desde a sua historicidade, expondo com regularidade reflexões e ações de cuidado para com os filhos mais carentes de cuidado.

Para que se realize a proteção e a garantia dos direitos fundamentais de crianças e adolescentes, em todas as esferas sociais, é de substancial importância identificar as possíveis causas da violência contra a população infantoadolescente, observado que a violência se configura como um fenômeno sociocultural plausível ao desenvolvimento de problemas sociais, físicos, emocionais, psicológicos e cognitivos, afetando a saúde coletiva e do indivíduo ao longo de sua vida. Para Silva et al. (2012), o trabalho preventivo com vistas à minimização desses danos é um conjunto de ações previstas no Estatuto da Criança e do Adolescente, demandando esforços de órgãos competentes que compõem o Sistema de Garantia de Direitos da Criança e do Adolescente.

As ações preventivas devem focar a eliminação ou redução dos fatores de risco e a ampliação dos fatores de proteção, ou redução da recorrência de violência e seus efeitos prejudiciais, sendo imprescindível o envolvimento do Poder Público (SILVA et al. 2012). 
Varios autores: o contexto da violência sexual contra criança e a necessidade de uma cultura de proteção familiar

A violência contra crianças e adolescentes têm impacto devastador, no entanto, grande parte dessa violência é previsível e pode ser evitada por meio de programas que abordem suas causas e fatores de risco. A prevenção, no entanto, exige a participação efetiva e imediata de todos na garantia de proteção à criança e ao adolescente, e nesse sentido, ações integradas, que visem maior eficácia das intervenções, devem ser priorizadas.

\section{CONSIDERAÇÕES FINAIS}

Com relação à legislação de proteção à criança, foi constatada sua abundância, incluindo a Convenção sobre os Direitos da Criança, a Constituição Federal, leis ordinárias, documentos da Igreja entre outras. No entanto, apenas no PNEVSCA há alguma intenção em iniciar o tratamento do AVS. Observou-se, nesta pesquisa, a falta, ou omissão, do legislador em estabelecer penas mais rígidas, como o afastamento imediato do suspeito do lar e, numa situação ideal, sua prisão imediata, pois são classificados como crimes hediondos. Pincolini et al. (2012) corroboram ser mais frequente a vítima ser recolhida em instituições do que o suspeito ser afastado do lar, fato que agrava seu sofrimento (em alguns casos, a denúncia).

O AVS, conforme aponta esta pesquisa, é uma pessoa normal e as diferenças socioeconômicas não são fatores predominantes para a prática da violência sexual, uma vez que esse crime ocorre em todos os níveis sociais, independentemente da classe em que esteja inserido o AVS. O que há é a probabilidade de ser menos denunciada nas classes sociais altas, nas quais o interesse econômico e o "status social", em geral, são preservados a qualquer custo. Diante da ocorrência da violência sexual em todas as classes sociais e da heterogeneidade do perfil do AVS, são importantes seu acompanhamento e tratamento, para evitar que o crime de violência sexual continue ocorrendo. 
Varios autores: o contexto da violência sexual contra criança e a necessidade de uma cultura de proteção familiar

Não foram encontradas pesquisa ou literatura que levasse em consideração a autonomia ou desenvolvimento moral do AVS, no máximo, debruça-se em descrever seu perfil biopsicossocial. Por fim, na comparação com outras pesquisas realizadas no país, verificou-se que o problema é uma barbárie cometida por um ser humano tão normal quanto aquele que é vítima. Mas, então, por que comete o ato de crueldade? As ações promovidas atualmente são embrionárias; se nascem, não perduram; se perduram, não se mantêm com qualidade de vida. Neste contexto, as estruturas eclesiais e o papel da religiosidade são fundamentais para uma mudança cultural com impacto social efetivo na sociedade.

Para romper o ciclo de violência, faz-se necessária a promoção da autonomia moral dos AVSs em seu mais amplo sentido, que se encaminha para a ação somente em seu próprio interesse, possibilitando que atinja um grau de autonomia moral que o leve a se preocupar com a vítima. Para tanto, o primeiro passo inclui ações, programas e divulgações diárias sobre os índices e a violência, não com sensacionalismo, mas com sensatez, trazendo à tona a dimensão do problema social e moral, que se encontra velado ou, então, banalizado. No sentido moral, a instituições religiosas tem papel fundamental para atuar na promoção de uma cultura de vida, de cuidado e proteção para com os vulneráveis, assim como promotora de justiça e da verdade.

Além da compreensão de quem é o AVS, faz-se necessário o cuidado especial para que a criança não se torne vítima de violência sexual, uma vez que, muitas vezes, essa agressão ocorre por falta de cuidados, ou seja, diante de uma oportunidade, o AVS age. Estratégias devem ser desenvolvidas com a finalidade de instruir as crianças a conhecer seu corpo e os limites de acesso a ele, de modo que sejam capazes de identificar uma ameaça e denunciá-la, bem como compreender o que é saudável e o que não é, pois as crianças depositam nos familiares e adultos que conforma seu cotidiano muita confiança, não sabendo muitas vezes identificar a violência sexual por eles cometido, acreditando que tal procedimento seja normal, uma demonstração de carinho, concluindo somente após anos que se tratava de abuso sexual. Essas estratégias educativas, além de empoderar as crianças 
Varios autores: o contexto da violência sexual contra criança e a necessidade de uma cultura de proteção familiar

para defenderem-se de uma possível violência sexual, têm caráter preventivo, pois a criança de hoje é o adulto de amanhã - a criança vitimada hoje pode vir a ser o AVS no futuro. Aprendendo a identificar uma violência sexual e conhecer os limites, ela também desenvolve sua sexualidade, de forma a não cometer essa violência sexual no futuro.

Um segundo passo é a promoção de educação social e eclesial voltada à autonomia de todos os cidadãos, principalmente das crianças, cuja formação e conhecimento proporcionem detectar ou identificar sinais de tentativa de abuso sexual, mesmo aqueles atos ou ações mais ingênuas que possam soar como carinho, mas que, na realidade, conformam a violência sexual. Essas ações devem ser conjuntas não somente entre os municípios e os estados, mas entre os países, como prevê a Declaração Universal sobre Bioética e Direitos Humanos, com a promoção dos direitos básicos à dignidade e à liberdade, rompendo o ciclo de violência. E é neste contexto que a religiosidade tem dimensões globais e profundas para uma mudança cultural de promoção da dignidade humana e proteção contra a violência sexual.

\section{REFERÊNCIAS}

- A LEI garante a proteção contra o abuso e a exploração sexual. Turminha do MPF, Direitos das Crianças, Proteção contra Abuso e Exploração Sexual. Disponível em: <http://www.turminha.mpf.mp.br/direitos-das-criancas/18-de-maio/copy_of_a-leigarante-a-protecao-contra-o-abuso-e-a-exploracao-sexual>. Acesso em: mar. 2017.

- ADORNO, Sérgio. A banalidade da violência contemporânea: o problema da anestesia moral. In: BREPOHL, Marion (Org.). Eichmann em Jerusalém 50 anos depois. Curitiba: Ed. UFPR, 2013. p. 79-102. 
Varios autores: o contexto da violência sexual contra criança e a necessidade de uma cultura de proteção familiar

- BALTIERI, Danilo Antônio. Consumo de álcool e outras drogas e impulsividade sexual entre agressores sexuais. 2005. 149 f. Tese (Doutorado em Medicina) - Faculdade de Medicina, Universidade de São Paulo, São Paulo, 2005.

- $\quad$ BEAUCHAMP, Tom L.; CHILDRESS, James. Princípios de ética biomédica. 4. ed. São Paulo: Loyola, 2002.

- BIAGGIO, Angela Maria Brasil. Kohlberg e a "comunidade justa": promovendo o senso ético e a cidadania na escola. Psicologia: Reflexão e Crítica, Porto Alegre, v. 10, n. 1, 1997.

Disponível em: <http://www.scielo.br/scielo.php?script=sci_arttext\& pid=S010279721997000100005>. Acesso em: 24 fev. 2017.

- BIOMETRIA: qui quadrado. $2011 . \quad$ Disponível em: <http://www.cultura.ufpa.br/dicas/biome/bioqui.htm>. Acesso em: 16 fev. 2017.

- $\quad$ BRASIL. Decreto-lei n. 2.848, de 7 de dezembro de 1940. Código Penal. Diário Oficial da União, Rio de Janeiro, 31 dez. 1940.

- _ _ C Constituição (1988). Constituição da República Federativa do Brasil. Brasília, DF: Senado Federal, 1988.

$-$ . Lei n. 8.069, de 13 de julho de 1990. Dispõe sobre o Estatuto da Criança e do Adolescente e dá outras providências. Diário Oficial da União, Brasília, DF, 16 jul. 1990. Disponível em: <http://www.planalto.gov.br/ccivil_03/leis/L8069.htm>. Acesso em: 22 fev. 2017.

_ _ _ Lei n. 11.419, de 19 de dezembro de 2006. Dispõe sobre a informatização do processo judicial; altera a Lei no 5.869, de 11 de janeiro de 1973 - Código de Processo Civil; e dá outras providências. Diário Oficial da União, Brasília, DF, 20 dez. 2006. 
Varios autores: o contexto da violência sexual contra criança e a necessidade de uma cultura de proteção familiar

- _ _ Ministério da Justiça. Comitê Nacional de Enfrentamento à Violência Sexual contra Crianças e Adolescentes. Plano Nacional de Enfrentamento da Violência Sexual Infanto-Juvenil: uma política em movimento. Relatório do Monitoramento 2003-2004. Brasília, DF: MJ, 2006 . Lei n. 12.015, de 7 de agosto de 2009. Altera o Título VI da Parte Especial do Decreto-Lei no 2.848, de 7 de dezembro de 1940 - Código Penal, e o art. 10 da Lei no 8.072, de 25 de julho de 1990, que dispõe sobre os crimes hediondos, nos termos do inciso XLIII do art. 50 da Constituição Federal e revoga a Lei no 2.252, de 10 de julho de 1954, que trata de corrupção de menores. Diário Oficial da União, Brasília, DF, 10 ago. 2009. Disponível em: <http://www.planalto.gov.br/ccivil_03/_Ato20072010/2009/Lei/L12015.htm\#art4>. Acesso em: 22 fev. 2017. . Presidência da República. Secretaria de Direitos Humanos. Plano Nacional de Enfrentamento da Violência Sexual contra Crianças e Adolescentes (PNEVSCA). Brasília, DF: DSH, 2013. Disponível em: <http://www.sdh.gov.br/assuntos/ bibliotecavirtual/criancas-e-adolescentes/publicacoes-2013/pdfs/plano-nacional-deenfrentamento-da-violencia-sexual-contra-criança-e-adolescente>. Acesso em: 7 jan. 2017.

- BRASIL. Lei n.13.431 de 04 de abril de 2017. Dispõe sobre o sistema de garantia de direitos de crianças e adolescentes vítimas e testemunhas de violência. Disponível em: http://www.planalto.gov.br/ccivil 03/ ato2015-2018/2017/lei/l13431.htm Acesso em 10 de abril de 2021.

- BRASIL. Emenda Constitucional no 65, de 13 de julho de 2010, 227 da CF/1988: Art. 227. É dever da família, da sociedade e do Estado assegurar à criança, ao adolescente e ao jovem, com absoluta prioridade, o direito à vida, à saúde, à alimentação, à educação, ao 
Varios autores: o contexto da violência sexual contra criança e a necessidade de uma cultura de proteção familiar

lazer, à profissionalização, à cultura, à dignidade, ao respeito, à liberdade e à convivência familiar e comunitária, além de colocá-los a salvo de toda forma de negligência, discriminação, exploração, violência, crueldade e opressão. Disponível em http://www.planalto.gov.br/ccivil_03/constituicao/constituicao.htm.

- SANTOS, Benedito Rodrigues dos. Redes de Proteção: Guia de Referência. Construindo uma Cultura de Prevenção à Violência Sexual. São Paulo: Childhood - Instituto WCFBrasil: Prefeitura da Cidade de São Paulo. Secretaria de Educação, 2009. p. 41 -42.

- CAFÉ, Monica Barcellos; NASCIMENTO, Nilton Inácio do. O psicodrama e o atendimento aos autores de violência sexual. Revista Brasileira de Psicodrama, São Paulo, v. 20, n. 2, p. 127-139, out. 2012. Disponível em: <http://pepsic.bvsalud.org/scielo.php?script=sci_arttext\&pid=S010453932012000200009\&Ing=pt\&nrm=i\&t|ng=pt>. Acesso em: 3 jan. 2017.

- CARVALHO, Luiz do Nascimento; SOUSA, Sônia Margarida Gomes. Perfil da população carcerária condenada por crimes contra mulheres, crianças e adolescentes em Goiás: autores, violência e vítima. In: OLIVEIRA, Maria Luiza Moura; SOUSA, Sônia Margarida Gomes de (Org.). (Re)descobrindo as faces da violência sexual contra crianças e adolescentes. Brasília, DF: Secretaria Especial de Direitos Humanos; Goiânia: Cânone, 2007.

- CHAUÍ, Marilena. Cultura e democracia./ Marilena Chauí. 2 ed. Salvador : Secretaria de Cultura, Fundação Pedro Calmon, 2009.

- CERQueIRA, Daniel; COELHO, Danilo Santa Cruz. Estupro no Brasil: uma radiografia segundo os dados da saúde (versão preliminar). Brasília, DF: IPEA, 2014. (Nota técnica; n. 11). Disponível em: <http://www.ipea.gov.br/portal/images/ stories/PDFs/nota_tecnica/140327_notatecnicadiest11.pdf>. Acesso em: 25 fev. 2017. 
Varios autores: o contexto da violência sexual contra criança e a necessidade de uma cultura de proteção familiar

- CHILDHOOd PELA PROTEÇÃO DA INFÂNCIA. Disque 100. 2017. Disponível em: <http://www.childhood.org.br/tag/disque-100>. Acesso em: 22 fev. 2017.

- COMITÊ NACIONAL DE ENFRENTAMENTO À VIOLÊNCIA SEXUAL CONTRA CRIANÇAS E ADOLESCENTES. Plano nacional de enfrentamento da violência sexual infanto-juvenil: uma política em movimento: relatório do monitoramento 2003-2004. Brasília, DF, 2006. Disponível em: $<$ http://www.crpsp.org.br/portal/comunicacao/diversos/mini_cd/pdfs/plano_nacional _pt1.pdf>. Acesso em: 22 fev. 2017.

- COSTA, Lucilene Paiva da. Características biopsicossociais de autores de agressão sexual de crianças e/ou adolescentes em contexto intrafamiliar e extrafamiliar. 2015. Dissertação (Mestrado em Teoria e Pesquisa do Comportamento) - Universidade Federal do Pará, Belém, 2015.

- CURITIBA. Mapa $2015 . \quad$ Disponível em: $<$ http://www.curitiba.pr.gov.br/fotos/album-novo-mapa-regionais/23644>. Acesso em: mar. 2017.

- GOLDIM, José Roberto. Princípio do respeito à pessoa ou da autonomia. 14 mar. 2004. Disponível em:<https://www.ufrgs.br/bioetica/autonomi.htm>. Acesso em: 7 abr. 2017.

- GRACIA, Diego. La autonomía moral: ¿mito o realidad? Palestra proferida no XIII Ateneo de Bioética La Autonomia a Examen, Zaragoza, em 7 nov. 2012. Disponível em: <https://vimeo.com/53224449>. Acesso em: 18 fev. 2017.

- HABIGZANG, Luísa Fernanda et al. Abuso sexual infantil e dinâmica familiar: aspectos observados em processos jurídicos. Psicologia: Teoria e Pesquisa, Brasília, DF, v. 21, n. 3, 
Varios autores: o contexto da violência sexual contra criança e a necessidade de uma cultura de proteção familiar

p. 341-348, set./dez. 2005. Disponível em: <http://www.scielo.br/pdf/ptp/ v21n3/a11v21n3.pdf>. Acesso em: 4 jan. 2017.

- HABIGZANG, Luísa Fernanda; RAMOS, Michele da Silva; KOLLER, Sílvia Helena. A revelação de abuso sexual: as medidas adotadas pela rede de apoio. Psicologia: Teoria e Pesquisa, Brasília, DF, v. 27, n. 4, p. 467-473, out./dez. 2011.

- HOHENDORFF, Jean Von et al. Documentary analysis of cases of sexual violence against boys reported in Porto Alegre. Paidéia, Ribeirão Preto, v. 24, n. 58, p. 187-196, maio/ago. 2014.

- INSTITUTO de Pesquisa e Planejamento Urbano de Curitiba (IPPUC). Disponível em: <http://www.ippuc.org.br/default.php?pagina=348>. Acesso em: mar. 2017.

- $\quad$ KAPPANN, Jair Izaías. Violência sexual contra crianças e adolescentes: um estudo sobre o perfil dos agressores. In: CONGRESSO INTERNACIONAL DE PSICOLOGIA DA UEM, 6., 2015, Maringá. Anais... Maringá: UEM, 2015.

- KRUG, Etienne G. et al. (Ed.). Relatório mundial sobre violência e saúde. Genebra: OMS, 2002. Disponível em: <http://www.opas.org.br/wp-content/uploads/2015/09/relatoriomundial-violencia-saude.pdf>. Acesso em: 31 jan. 2017.

- LAVORATTI, Cleide. Tecendo a rede de proteção: desafios do enfrentamento intersetorial à violência intrafamiliar contra crianças e adolescentes no município de Curitiba/PR. 2013. 318 f. Tese (Doutorado em Sociologia) - Universidade Federal do Paraná, Curitiba, 2013.

- $\quad$ LUNG, For-Wey; HUANG, Shu-Fen. Psychosocial characteristics of criminals committing incest and other sex offenses: a survey in a Taiwanese prison. International Journal of 
Varios autores: o contexto da violência sexual contra criança e a necessidade de uma cultura de proteção familiar

Offender Therapy and Comparative Criminology, v. 48, n. 5, p. 554-560, 2004. Disponível em: <http://journals.sagepub.com/doi/pdf/ 10.1177/0306624X04265083>. Acesso em: 10 jan. 2017.

- MARTINS, Christine Baccarat de Godoy; JORGE, Maria Helena Prado de Mello. Abuso sexual na infância e adolescência: perfil das vítimas e agressores em município do Sul do Brasil. Texto \& Contexto Enfermagem, Florianópolis, v. 19, n. 2, p. 246-255, abr./jun. 2010.

- OLIVEIRA, Laize Fonseca. Perfil da violência sexual contra crianças e adolescentes em Sergipe: dados da capital e do interior. 2013. Dissertação (Mestrado em Psicologia Social) - Universidade Federal de Sergipe, São Cristóvão, 2013.

- ORGANIZAÇÃO DAS NAÇÕES UNIDAS PARA A EDUCAÇÃO, A CIÊNCIA E A CULTURA (UNESCO). Declaração universal sobre bioética e direitos humanos. Genebra, 2005. Disponível em: <http://unesdoc.unesco.org/images/0014/001461/ 146180por.pdf>. Acesso em: 22 fev. 2017.

- PFEIFFER, Luci; SALVAGNI, Edila Pizzato. Visão atual do abuso sexual na infância e adolescência. Jornal de Pediatria, Rio de Janeiro, v. 81, n. 5, p. S197-S204, nov. 2005.

- PINCOLINI, Ana Maria Franchi; HUTZ, Cláudio Simon. Abusadores sexuais adultos e adolescentes no Sul do Brasil: pesquisa em denúncias e sentenças judiciais. Temas em Psicologia, São Paulo, v. 22, n. 2, p. 301-311, 2014.

- PINCOLINI, Ana Maria Franchi; HUTZ, Cláudio Simon; LASKOSKI, Lorena. Caracterização da violência sexual a partir de denúncias e sentenças judiciais. Psicologia em Pesquisa, Juiz de Fora, v. 6, n. 1, p. 19-28, jan./jun. 2012. Disponível em: <http://pepsic.bvsalud.org/pdf/psipesq/v6n1/v6n1a04.pdf>. Acesso em: 10 jan. 2017. 
Varios autores: o contexto da violência sexual contra criança e a necessidade de uma cultura de proteção familiar

- PORTAL ACTION. Quartis. 2017. Disponível em: <http://www.portalaction.com.br/ estatística-básica/23-quartis>. Acesso em: 16 fev. 2017.

- $\quad$ SILVA, Lygia Maria; FERRIANI, Maria das Graças; SILVA, Marta Angélica. Violência sexual intrafamiliar contra crianças e adolescentes: entre a prevenção do crime e do dano. Rev. Bras. Saúde Matern. Infant., Recife, 12 (4): 403-411 out. / dez., 2012

- SISTEMA DE INFORMAÇÕES PARA INFÂNCIA E ADOLESCÊNCIA (SIPIA). Módulo para conselhos tutelares. $2017 . \quad$ Disponível em: <http://www.sipia.gov.br/CT/?x=zOD2cdso8LpBB8yQLcmCDQ>. Acesso em: 22 fev. 2017.

- $\quad$ TEICHER, Martin H. et al. The neurobiological consequences of early stress and childhood maltreatment. Neuroscience and Biobehavioral Reviews - Elsevier Science Ltd - USA, v.27, p.33-44, 2003.

- WAISELFISZ, Julio Jacobo. Mapa da violência 2012: crianças e adolescentes do Brasil. Rio de Janeiro: CEBELA, 2012. Disponível em: <http://www.crianca.mppr.mp. br/arquivos/File/publi/xtras/mapaviolencia2012_criancas_e_adolescentes.pdf $>$. Acesso em: 19 jan. 2017.

- WILlIAMS, Lucia C. de Albuquerque. Pedofilia: identificar e prevenir. São Paulo: Brasiliense, 2012 